\title{
Comparison of Leaf Moisture Content and Ignition Characteristics among Native Species and Exotic Conifers in Northwestern Patagonia, Argentina
}

\author{
Lucas O. Bianchi ${ }^{\circ}$, Facundo J. Oddi, Miriam Muñoz, and Guillermo E. Defossé
}

The forest-steppe ecotone in Argentine Patagonia has been planted with non-native Pinus ponderosa, Pseudotsuga menziesii, Pinus radiata, and P. contorta. As in many other planted areas of the Southern Hemisphere, there is great concern about increasing landscape flammability. We determined, under lab conditions, live fuel moisture content (LFMC) and leaf ignition of these conifers, a naturalized poplar, and 13 native species. The mean LFMC was inversely related to leaf ignition of these species. The conifer LFMC was lower than that of most natives, making the conifers the most ignitable species. Pinus ponderosa and Pseudotsuga menziesii showed the spring dip phenomenon (i.e., low LFMC in early spring). Leaf ignition and LFMC may help elucidate some flammability components at species levels. At landscape scales, however, they have to be evaluated along with other landscape traits such as structure and stand composition. Understanding this landscape context will require full-scale experimental fires. Nevertheless, our results provide useful information for fire danger assessment, and also for setting policies aimed at planning and applying appropriate silvicultural techniques for fire prevention and control, and hence reducing fire danger at stand or landscape levels.

Keywords: flammability, pine plantation, fuel management, forest fires, leaf traits

$\mathrm{T}$ The forest-steppe ecotone of Patagonia, Argentina, is a narrow strip of land of about 4 million hectares along the eastern side of the Andes. This ecotone has a sharp precipitation gradient, decreasing from $4,000 \mathrm{~mm}$ to $400 \mathrm{~mm}$ per year over less than $80 \mathrm{~km}$ from the Andean timberline toward the eastern steppe (Veblen et al. 1992). As in any Mediterranean-type climate ecosystem (humid winters and hot, dry summers), vegetation in this ecotone is prone to wildfires during the dry season (Kitzberger and Veblen 2003, and references therein). Fires are more frequent and less severe in low ecotone areas where native grasses and shrubs dominate, and less frequent but more severe at high elevations of the Andean mountains occupied by Nothofagus and other tree species (Veblen et al. 2008). Although native shrub-steppe vegetation recovers quickly after wildfire events (Defossé et al. 2015), plantation efforts in this ecotone require careful planning according to the frequency of fire occurrence.
During the last century, the ecotone landscape was mainly used for livestock production and forest logging. In the last 30 years, however, economic and ecological constraints (low prices of wool and meat at international markets, land degradation by overgrazing, and unsustainable native forest management) have led stakeholders (e.g., government agencies, researchers, concerned citizens) to focus on other economic activities. As in many other temperate areas of the southern Hemisphere (Simberloff et al. 2009), many ranchers from the central western Patagonia $\left(38-46^{\circ} \mathrm{S}\right)$ replaced traditional land uses with exotic conifer plantations for timber production. Currently, about 100,000 hectares are planted; mainly (80\%) with Pinus ponderosa (Dougl.) ex Laws, and Pseudotsuga menziesii (Mirb.) Franco plantations account for an additional 10\%. The remaining sites are planted with Pinus radiata D. Don and $P$. contorta Dougl. var. latifolia (Engelm) (Defossé et al. 2015). Most of these plantations are less than 25 years old. Another exotic tree that has

Manuscript received August 7, 2017; accepted October 4, 2018; published online December 7, 2018.

Affiliations: Lucas O. Bianchi (lbianchi@conicet.gov.ar), Instituto Argentino de Nivología, Glaciología y Ciencias Ambientales—Consejo Nacional de Investigaciones Cientificas y Técnicas (CONICET), Argentina.Facundo J. Oddi (foddi@unrn.edu.ar), Instituto de Investigaciones en Recursos Naturales, Agroecología y Desarrollo Rural, Universidad Nacional de Río Negro, Sede Andina_CONICET, Argentina. Miriam Muñoz (miriammmunoz@yahoo.com.ar), Consejo Agrario Provincial Los Antiguos, Santa Cruz, Agentina. Guillermo E. Defossé (gdefosse@ciefap.org.ar), Centro de Investigación y Extensión Andino Patagónico-CONICET and Facultad de Ingeniería, Universidad Nacional de la Patagonia San Juan Bosco, Sede Esquel, Argentina.

Acknowledgments: We want to thank Helga J. Kirner for her collaboration in field sampling and sample processing. Weather data were provided by the National Weather Service (Servicio Meteorológico Nacional, SMN) of Argentina. 
been widely planted in this region is the non-native Populus nigra var. italica (Munch.) Koehne (Bianchi and Defossé 2015).

Fire has been relatively uncommon in Patagonian plantations, with only about $3 \%$ of sites burning annually. However, this percentage may increase in the near future because of stand aging, lack of density management, and climate change (Defossé et al. 2011, Godoy et al. 2013). Although the fire ecology of the region is well studied (Defossé et al. 2015, Oddi and Ghermandi 2016, and references therein) and the flammability of native trees and shrubs has recently been evaluated (Blackhall et al. 2012, Bianchi and Defossé 2014, 2015, Ghermandi et al. 2016), little is known about the effects of LFMC on leaf ignition of conifer plantations or how these effects compare to native vegetation.

Although the flammability of live fuels cannot solely be explained by their moisture content (Jervis et al. 2010, McAllister et al. 2012), this parameter is one of the most important factors regulating the ignition and spread of wildland fires in Patagonia (Bianchi and Defossé 2014, 2015) and elsewhere (Rothermel and Anderson 1966, Xanthopoulos and Wakimoto 1993, Dimitrakopoulos and Bemmerzouk 2003, Jolly et al. 2012). Furthermore, flammability and fire risk can be greatly modified in ecosystems when new species are introduced (Brooks et al. 2004, Gill and Zylstra 2005, Peña-Fernández and Valenzuela-Palma 2008, Fraser et al. 2016).

In their native ranges, the exotic conifers planted in the study area evolved in the presence of fire (Wright and Bailey 1982, Agee 1993). The vegetation of the forest-steppe ecotone is also fireadapted (González 2011, Defossé et al. 2015, Oddi and Ghermandi 2016). However, the combination of recurrent fires and pine plantations without appropriate management could lead to more frequent and severe fires (Raffaele et al. 2015). Also, this cycle may enhance the possibility that the non-native species become invasive (Sarasola et al. 2006, Orellana and Raffaele 2010). This has led to controversy in Patagonian society regarding the most appropriate land-management schemes. Although some groups are concerned that plantations may greatly increase flammability and fire risk at either the stand or landscape level (Raffaele et al. 2015), others suggest that well-managed stands would not have negative effects at these scales and that exotic conifer plantations would not result in environmental damage (Davel et al. 2015).

We conducted our study to help resolve this controversy. Our objectives were: (1) to determine the effect of LFMC on leaf ignition of commonly planted exotic conifers (Pinus ponderosa, Pseudotsuga menziesii, Pinus radiata, and P. contorta) and a broadleaf species (Populus nigra), as well as of the most abundant native shrubs and trees from the region; (2) to model the seasonal dynamics of LFMC in the most critical period of a typical fire season for all the selected species; (3) to model diurnal LFMC dynamics of Pinus ponderosa (the most commonly planted species) at 2-h intervals during one entire fire season; (4) based on the results of the study, to provide rangers, land owners, and policymakers of the Patagonian region with a basis for planning adequate conifer planting and management schemes to reduce landscape flammability and fire danger. This study will not only increase the knowledge about vegetation flammability in Patagonia but also provide management guidelines for regions around the globe that share similar Mediterranean climate and vegetation conditions in which plantations are planned.

\section{Materials and Methods}

\section{Study Area and Species Evaluated}

The study area was located nearby the town of Esquel, in northwestern Patagonia, Argentina (42 $55^{\prime} \mathrm{S}, 71^{\circ} 21^{\prime} \mathrm{W}$; Figure 1a). Native vegetation gradually changes from steppe to humid forests along a steep precipitation gradient, from less than $400 \mathrm{~mm} \mathrm{year}^{-1}$ in the east to more than 1,000 $\mathrm{mm}_{\text {year }}{ }^{-1}$ in the west (Buduba 2006, Figure 1a). In the dry east, native grasses of the genera Pappostipa, Poa, Festuca, and Bromus, together with the native shrubs Mulinum spinosum (Cav.) Pers., Fabiana imbricata (Ruiz \& Pav.), Adesmia sp., and Senecio sp., dominate the landscape (Defossé et al. 2015, Oddi and Ghermandi 2016). Toward the west, where annual precipitation and altitude increase, vegetation becomes dominated by native forests mainly composed of Austrocedrus chilensis (D. Don) Pic. Serm. \& Bizarri and Nothofagus antarctica (G. Forst.) Oerst, accompanied by Maitenus boaria (Mol.), and the tree-like species Schinus patagonicus (Phil.) I. M. Johnst. ex Cabrera, and Lomatia hirsuta (Lam.) Diels ssp. obliqua (Ruiz \& Pav.) R. T. Penn. Intermingled with these trees and tree-like species are the common shrubs Berberis microphylla (Juss. ex Poir.), B. darwinii (Phil.) and Ribes magellanicum (Poir.), together with the bamboo-like Chusquea culeou E. Desv. Chusquea culeou forms dense thickets in the landscape that intermix with other vegetation types up to the timberline and is one of the key species in propagating wildfires. Toward the west, Nothofagus dombeyi (Mirb.) Oerst forests dominate in humid sites, whereas Nothofagus pumilio (Poepp. \& Endl.) Krasser 1896 forests prevail on upper areas of the Andean mountain range up to the timberline.

As in western North America, the native range of the conifers planted in Patagonia, a Mediterranean-type of climate (Keeley et al. 2012) characterizes this ecotone region of Patagonia. Precipitation is concentrated during winter and early spring, followed by a dry period that lasts from late spring to early fall (mid-November to early March in the Southern Hemisphere; Figure 1b; Villalba 1995). The fire season coincides with this dry period, during which

\section{Management and Policy Implications}

Our lab results showed that live fuel moisture content (LFMC) is lower, and leaf ignition higher in exotic conifers than in most native species in Patagonia. Populus nigra showed the lowest leaf ignition parameters. Besides, Pinus ponderosa and Pseudotsuga menziesii, have extremely low LFMC in early spring (spring dip), when the wildland fire control system is not yet fully operational. These results are useful for understanding flammability of individual plants and can also be used as inputs for fire behavior models. However, they cannot be directly used as a surrogate for determining landscape flammability. In addition, leaf and canopy traits, stand density, and fuel distribution, among others characteristics, should be considered. For reducing fire risk posed by conifer afforestations, initial diminution of plantation density, reductions in density, and elevation of canopy height of old plantations, accompanied by prescribed burning and other slash treatments, and establishing lines of Populus nigra poplar within conifer stands seems to be the best solution. These findings should promote further research into silvicultural techniques to reduce fire risk in Patagonian afforestations. Rangers, foresters, and policymakers should use this basic information for planning conifer planting and management schemes aimed at reducing landscape flammability. 


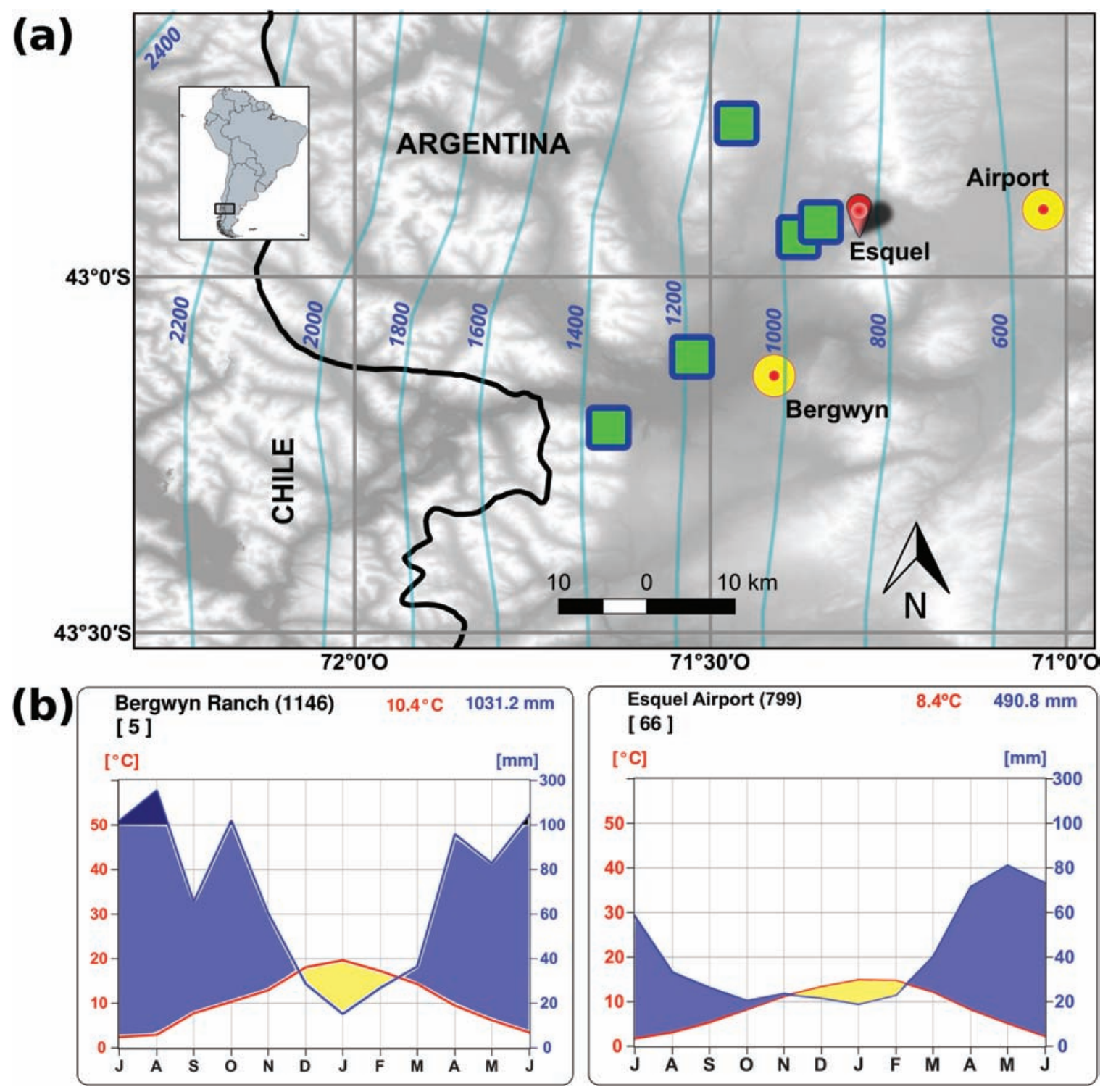

Figure 1. (a) Map showing the location of the five sampling sites (squares), the city of Esquel and the two weather stations. (b) Climate diagrams (Walter and Lieth 1960-1967) based on monthly data gathered from the Esquel airport (1949-2016) and from a remote automated weather station, located in the Bergwyn Ranch (2007-2012). Isohyets showing the marked precipitation gradient of the region. Data from the Esquel Airport weather station provided by the Argentinean National Weather Service (Servicio Meteorológico Nacional, SMN).

westerly wind speeds increase (Defossé 1995), increasing the risk and spread of fire. Most soils of the region originated from postglacial pyroclastic deposits (volcanic ashes, lapilli layers, or glacial deposits contaminated with volcanic sands). These volcanic deposits allowed for the development of high-fertility soils. Although the more humid areas are dominated by andisols, characterized by the presence of amorphous aluminosilicate (allophane and imogolite), the drier zone is a transitional area between xerands and andic mollisols (La Manna 2005).

We analyzed and compared LFMC and leaf ignition of 18 species. Sampled species comprised the four exotic conifers planted in Patagonia: Pinus ponderosa, Pseudotsuga menziesii, Pinus radiata, and P. contorta. The rest were all native species and comprised the trees Nothofagus pumilio, N. dombeyi, and Maitenus boaria; and the shrubs Mulinum spinosum, Fabiana imbricata, Ribes magellanicum, Berberis microphylla, and B. darwinii. We supplemented our work with previous data on leaf ignition and LFMC for the native trees Nothofagus antarctica, Austrocedrus chilensis, Schinus patagonicus, and Lomatia hirsuta; the bamboo-like Chusquea culeou; and the exotic Populus nigra (see Bianchi and Defossé 2015).

\section{Field Sampling}

We carried out the field sampling in five sites distributed along the precipitation gradient (Figure 1a). Sampling was repeated every 15 days from December to April (summer), covering the late part of the growing season (Jobbagy et al. 2002) and the period of high wildfire occurrence in northern Patagonia (Oddi and Ghermandi 2016). To test the decrease in LFMC during spring, a phenomenon known as "spring dip" (Jolly et al. 2016), we also sampled exotic conifers fortnightly during August and September. At every sampling date, between noon and 16:00, we randomly selected 10 individuals per species and collected $\sim 100 \mathrm{~g}$ of living leaves per 
tree (resulting in $-1,000 \mathrm{~g}$ per species) on the north side of the crown (the sunniest part of the tree), up to a height of $2 \mathrm{~m}$. Leaf samples were combined in the field and packed in individual hermetic bags. They were weighed in the field to obtain their fresh weight $(F W)$ and then taken to the lab in a portable fridge. Once in the lab, $-500 \mathrm{~g}$ of each species was oven-dried at $80^{\circ} \mathrm{C}$ for $48 \mathrm{~h}$ and reweighed to obtain the dry weight (DW). We used the remaining leaf samples (other $-500 \mathrm{~g}$ of each species) for the leaf ignition tests. We calculated the LFMC of each species as follows (Pellizzaro et al. 2007):

$$
\operatorname{LFMC}(\%)=(\mathrm{FW}-\mathrm{DW}) / \mathrm{DW} \times 100
$$

Besides seasonal LFMC dynamics and leaf ignition of the selected species, we determined the daily variation of LFMC of Pinus ponderosa needles weekly from January to March 2008. We collected needle samples randomly from 10 different trees every $2 \mathrm{~h}$ from early morning (09:00 am) to early evening (19:00 pm). For determining LFMC, we followed the same procedure as mentioned above. This intensive, time-consuming sampling was only done with Pinus ponderosa because it is the most planted species in the region and hence the main exotic tree that may be affected by wildfires in Patagonia.

\section{Leaf Ignition Tests}

Each ignition test included 70 subtests. For each subtest, we randomly took some leaves from the collected samples and put them inside a Petri box. Leaves were weighed in a precision balance $(0.1 \mathrm{~g}$ resolution) to obtain $1 \mathrm{~g}$ of their FW. These subsamples were then put over a standard epiradiator of $500 \mathrm{~W}$. A pilot flame, located $4 \mathrm{~cm}$ above the center of the epiradiator, allowed the ignition of the air-gas mixture resulting from the thermal decomposition of the subsample, but it did not play any part in this decomposition. In each subtest, we measured four parameters: (1) ignition time: the time lapse between the moment we put the sample over the epiradiator and the appearance of the first flame; (2) combustion duration: the duration of the flame (in seconds) after ignition; (3) ignition frequency: the proportion of positive subtests over the 70 subtests performed (a subtest was considered positive if the ignition time was less than $60 \mathrm{~s}$ ); and (4) flame index, which ranged from 1 to 5 based on flame height (1: flames $<1 \mathrm{~cm}$ tall; 2: flames $1-2 \mathrm{~cm}$; 3: flames 3-7 cm; 4: flames $8-12 \mathrm{~cm}$; 5 : flames $>12 \mathrm{~cm}$ tall). The final values of ignition time, combustion duration, and flame index were averaged over the 70 subtests.

\section{Data Analyses}

We computed all the statistical analyses using $\mathrm{R}$ software, version 3.2.3 (R Core Team 2015). To evaluate the effect of LFMC on leaf ignition (objective 1) we applied a multilevel modeling (or partial pooling) approach (Gelman and Hill 2007) using the "Ime" function from the "nlme" package (Pinheiro et al. 2016). For ignition time, combustion duration, and flame index (continuous response variables), these data were structured hierarchically within species. According to this hierarchy, we used species as a random factor and fitted a two-level linear model in which the random effect of species was modeled through a linear relation with the species-level LFMC (the mean LFMC of each species). We used varIdent as the variance function (Pinheiro and Bates 2006) when we detected that residual variance was different among species.
For ignition probability, we used a generalized linear mixed model with binomial distribution ("glmer" function from the "lme4" packages; Bates et al. 2015). Ignition probability has two possible responses: "ignited" or "not ignited." It was analyzed at test level with responses nested within samples (random factor; each sample was formed by 70 tests), nested within species (random factor). We related the random effect of species to the species-level LFMC. Additionally, we fitted simple linear regressions to study the relations among each one of the four ignition parameters and the LFMC for individual species. This analysis allowed us to assess the response of each species to changes in the LFMC. Finally, we combined the LFMC and the results of the four ignition parameters for each species using a principal-components analysis (PCA) and grouped the species according to their leaf ignition characteristics, with a hierarchical cluster analysis.

To analyze the seasonal dynamics of LFMC (objective 2), we applied a general linear model and varIdent as the variance function to model the heterogeneity among species. We modeled the mean LFMC as a function of time (continuous predictor) and species (categorical predictor). We incorporated species into the model as a fixed effect to evaluate the influence of each species on LFMC variations. The model was fitted using Pinus ponderosa as the reference level because it is the main planted exotic conifer. Therefore, we performed a posteriori comparisons with respect to this species. To adjust these models, we used LFMC and leaf ignition data gathered from December to April. We did not observe any temporal correlation, and so it was not necessary to include it into the model. For this analysis, we applied the "gls" function from the "nlme" package (Pinheiro et al. 2016).

To model the daily LFMC dynamics of Pinus ponderosa (objective 3), we used a multilevel approach with errors correlated in time. Our approach assumed that data corresponding to a same day are not independent, and consecutive data (e.g., LFMC at 09:00 versus LFMC at 11:00) are more similar than time-separate data (e.g., LFMC at 09:00 versus LFMC at 19:00). Therefore, we considered day as a random factor and applied an autoregressive moving mean error structure (Pinheiro et al. 2016). In addition, we used varIdent as the variance function to model heterogeneity among days. We included a proxy of the time of the fire season (number of weeks since the first sampling) to model the change in LFMC daily dynamics along the season (i.e., as a continuous predictor at the day level). We obtained a random intercept and slope model with temporal autocorrelation and heterogeneity considering day as the random factor, hour as the fixed effect at the data level, and time in the fire season as the fixed effect at the day level.

\section{Results \\ Relation between LFMC, Leaf Ignition, and Ignition Rating}

When considering all species together, LFMC was significantly related to the four leaf ignition parameters. According to the fitted models, ignition time increased by $0.08 \mathrm{~s}$ when the LFMC of species increased by one unit $\left(t_{\mathrm{df}: 16}=2.54 ; P=.021\right)$. In contrast, combustion duration decreased by $0.07 \mathrm{~s}$ per percentage unit of $\operatorname{LFMC}\left(t_{\mathrm{df}: 16}=-5.44 ; P<.0001\right)$; ignition frequency decreased by $6.0 \%$ per unit of LFMC (logit slope $=-0.06, t_{\mathrm{df}: 16}=-6.56 ; P<$ $.0001)$; and flame index decreased by 0.01 units per unit of LFMC $\left(t_{\mathrm{df}: 16}=-4.73 ; P<.0001 ;\right.$ Figure 2$)$. 

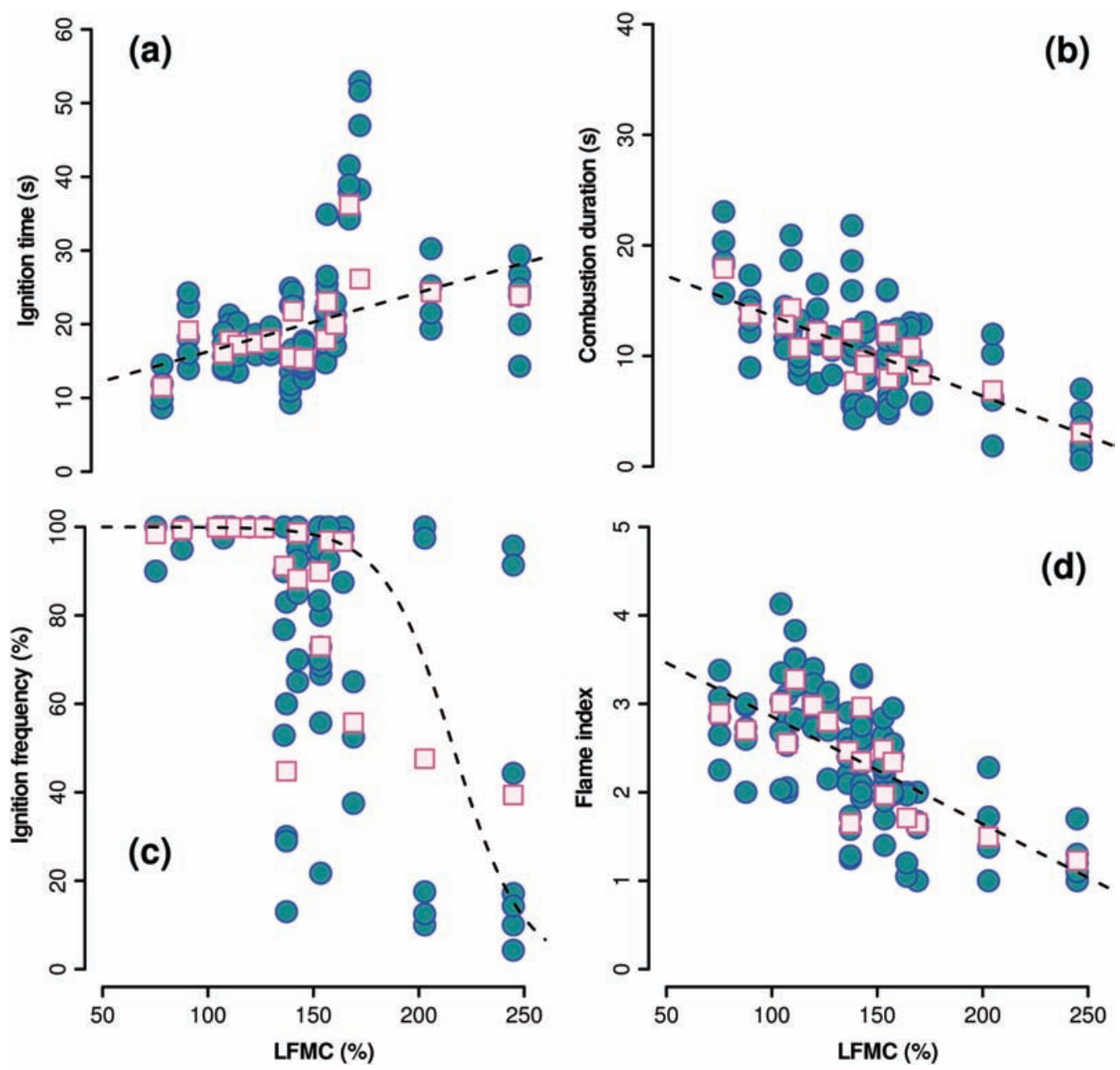

Figure 2. Observed (circles) and fitted (squares) values of the four leaf flammability parameters plotted against mean live fuel moisture content (LFMC, predictor at species level) considering all species together. Dotted lines represent the fitted curve for the estimated mean of the species random effect. (a) IT $=8.49-0.08$ LFMC $_{s}$ (b) $C_{s}=20.73-0.07$ LFMC $_{s}$ (c) IF $=e^{\wedge}\left(12.10-0.06\right.$ LFMC $\left._{s}\right) / 1+e^{\wedge}(13.10-0.06$ $\mathrm{LFMC}_{s}$ ); and (d) $\mathrm{FI}_{\mathrm{s}}=4.07-0.01 \mathrm{LFMC}_{\mathrm{s}}$. IT, ignition time; CD, combustion duration; IF, ignition frequency; FI, flame index. The subscript "s" indicates species.

LFMC was similar for the four exotic conifer species and generally below the LFMC of native trees (Table 1); in this sense, leaf ignition parameters were higher in exotic conifers than in native trees. The exotic Populus nigra had the lowest values of leaf ignition and the highest mean LFMC. Shrub values were more variable. Although Schinus patagonicus, Fabiana imbricata, Ribes magellanicum, and Mulinum spinosum showed relatively low levels of leaf ignition, both Berberis microphylla and B. darwinii had lower LFMC and higher levels of leaf ignition than native trees. Moreover, ignition of Berberis microphylla leaves was higher than that of the exotic conifers, and only surpassed by Chusquea culeou, which had the lowest LFMC and the highest leaf ignition values of all species analyzed.

Most of the leaf ignition parameters were not highly modified by changes in LFMC when considered within species (Table S1). Among conifers, only the combustion durations of Pseudotsuga menziesii and Pinus ponderosa were slightly influenced by changes in LFMC. In Populus nigra, the relation of LFMC with combustion duration and flame index was slightly significant. Relations of LFMC with ignition variables for native trees differed by species. LFMC influenced the combustion duration of Nothofagus antarctica and Maitenus boaria, the ignition time of Nothofagus antarctica, and the flame index of $N$. pumilio. It is remarkable that Austrocedrus chilensis is the only species in which changes of all the four leaf ignition parameters were significantly associated with changes in LFMC. Considering shrubs, the relation was significant only in the ignition time of Ribes magellanicum and Mulinum spinosum, and in the combustion duration of Mulinum spinosum.

The PCA for leaf ignition of the 18 species explained $88.8 \%$ of the variation with the first two principal components (Figure 3). All parameters were closely related to Axis 1 (PCF1) explaining 71.2\% of the variance, and Axis 2 (PCF2) added $17.6 \%$ of the variation of leaf ignition. Combustion duration, ignition frequency, and flame index were positively correlated with PCF1 $(0.8,0.9$, and 0.9 , respectively) and poorly correlated with PCF2 $(<0.4)$. Contribution of these parameters was 22.6, 29.6, and 30.3\% to PCF1, and 26.9, 8.0, and $1.4 \%$ to PCF2, respectively. On the other hand, ignition time was negatively correlated with PCF1 $(-0.7)$, and its contribution to this axis was $17.5 \%$, but it was positively correlated with PCF2 (0.7), to which it highly contributes (63.7\%). The results of the hierarchical cluster analysis grouped the species in six clusters according to their ignition parameters (Table 1 and dotted ellipses 
Table 1. Fitted values for the four leaf ignition parameters and LFMC at the species level.

\begin{tabular}{|c|c|c|c|c|c|c|c|}
\hline Type & Species & Leaf ignition category & $\begin{array}{l}\text { Ignition } \\
\text { time }(s)\end{array}$ & $\begin{array}{l}\text { Combustion } \\
\text { duration (s) }\end{array}$ & $\begin{array}{l}\text { Flame } \\
\text { index }\end{array}$ & $\begin{array}{l}\text { Ignition } \\
\text { frequency (\%) }\end{array}$ & LFMC (\%) \\
\hline \multirow[t]{4}{*}{ Exotic conifers } & Pinus ponderosa & Highly ignitable & 17.4 & 12.2 & 3.0 & 100.0 & 119.7 \\
\hline & Pseudotsuga menziesii & Highly ignitable & 17.8 & 14.8 & 2.5 & 99.6 & 107.2 \\
\hline & Pinus contorta & Highly ignitable & 17.2 & 10.0 & 3.6 & 100.0 & 111.0 \\
\hline & Pinus radiata & Highly ignitable & 17.9 & 10.4 & 2.8 & 100.0 & 126.7 \\
\hline Exotic broadleaf & Populus nigra & Poorly ignitable & 22.9 & 3.1 & 1.2 & 40.4 & 252.0 \\
\hline \multirow[t]{7}{*}{ Native trees } & Nothofagus dombeyi & Highly ignitable & 16.0 & 12.6 & 3.0 & 100.0 & 104.3 \\
\hline & Nothofagus antarctica & Very ignitable & 15,0 & 12,6 & 2,5 & 91,1 & 135.6 \\
\hline & Nothofagus pumilio & Very ignitable & 15.2 & 9.4 & 2.3 & 87.8 & 142.5 \\
\hline & Lomatia hirsuta & Very ignitable & 17.7 & 13.2 & 2.5 & 89.7 & 152.8 \\
\hline & Maitenus boaria & Very ignitable & 19.9 & 9.2 & 2.4 & 97.0 & 157.4 \\
\hline & Austrocedrus chilensis & Ignitable & 23.3 & 7.5 & 1.9 & 72.7 & 153.4 \\
\hline & Schinus patagonicus & Ignitable & 21.9 & 6.2 & 1.5 & 43.0 & 137.2 \\
\hline \multirow[t]{5}{*}{ Native shrubs } & Berberis microphylla & Highly ignitable & 19.5 & 13.5 & 2.7 & 99.2 & 87.7 \\
\hline & Berberis darwinii & Highly ignitable & 15.2 & 8.5 & 3.1 & 98.8 & 142.6 \\
\hline & Fabiana imbricata & Moderately ignitable & 37.5 & 11.7 & 1.6 & 97.0 & 164.0 \\
\hline & Mulinum spinosum & Moderately ignitable & 47.5 & 8.2 & 1.6 & 55.0 & 169.1 \\
\hline & Ribes magellanicum & Poorly ignitable & 24.3 & 7.3 & 1.5 & 47.5 & 202.8 \\
\hline Native bamboo & Chusquea culeou & Extremely ignitable & 11.4 & 19.2 & 2.8 & 98.0 & 75.2 \\
\hline
\end{tabular}

Note: Species are categorized according to the results of the hierarchical cluster analysis.

in Figure 3). The more ignitable species had large positive values for PCF1, whereas the less ignitable species had large negative values in this axis. Because PCF2 has very few contributions of most parameters, only two species, Mulinum spinosum and Fabiana imbricata, which had high ignition times, were differentiated in this axis (Figure 3).

\section{LFMC Dynamics}

LFMC dynamics varied widely among species and vegetation types (Figure 4 and Table S2). The LFMC of exotic conifers varied around a mean value of $117.4 \% \pm 10.8$. The LFMC of Pinus radiata increased as the season advanced. The other three conifers, instead, showed a decreasing LFMC trend along the fire season (Pinus ponderosa was the reference level with LFMC decreasing at a rate of $0.14 \%$ day $\left.^{-1}\right)$. The exotic broadleaf Populus nigra had the highest LFMC mean of all the species studied $(252.0 \%)$ and also was relatively more variable (residual standard error $=28.8$ ). Among the native forest species, Nothofagus dombeyi had the lowest mean LFMC (104.3\%) with a relatively small variability around its temporal trend (residual standard error $=6.1$ ). Live FMC of the other six native forest species was higher (greater than 135.5\%) and more variable. The LFMC trend in Nothofagus antarctica, Austrocedrus chilensis, and Nothofagus pumilio was similar to that of Pinus ponderosa. On the other hand, whereas Schinus patagonicus and Lomatia hirsuta had increasing LFMC, Maitenus boaria decreased dramatically during the season $\left(0.86 \%\right.$ day $\left.^{-1}\right)$. With the exception of Fabiana imbricata, LFMC of all shrub species decreased as the season progressed. In particular, Mulinum spinosum had the highest drying rate of all species evaluated (i.e., the most negative slope). This drying trend separated the shrubs into two groups. The first group included Berberis microphylla and B. darwinii, with mean LFMC values below those of the native tree species. The rest of the shrubs form the second group, which had generally higher LFMC values than all tree species $(168.0 \% \pm 31.4)$. Although Chusquea culeou had the lowest LFMC values throughout the season (Table 1), its temporal trend was similar to that of Pinus ponderosa. It is important to note that the lowest values of LFMC in Pinus ponderosa $(-110.2 \%)$ and in Pseudotsuga menziesii $(-87.1)$ occurred during September-October (spring in the southern Hemisphere), but in Pinus contorta $(-97.3 \%)$ and P. radiata $(-118.8 \%)$ the lowest LFMC values were registered during January (summer) and March (early fall), respectively.

\section{Daily Variation of LFMC in Pinus ponderosa}

The daily variation of LFMC in Pinus ponderosa was minimal (less than 15\%), but the pattern of daily variation changed during the growing season. From January to mid-February, LFMC reached a minimum around noon (Figure $5 \mathrm{a}-\mathrm{d}$ ). The timing of this minimum shifted to 15:00-17:00 from late February to the end of the season (late April); the highest LFMC was observed at 09:00 (Figure 5e-1). Thus, there was a significant interaction effect $(P=.018)$ between the hour of day and the moment of the fire season. The initial LFMC (at 09:00) tended to remain constant during the fire season (Figure $5 \mathrm{~m}$ ), but the slope in the hourly dynamics (i.e., the change in LFMC during the day) decreased by 0.19 unit per week (Figure 5n).

\section{Discussion}

The degree to which plant traits, rather than climate or weather, influence flammability and subsequent fire behavior is still a matter of ongoing debate (Mutch 1970, Troumbis and Trabaud 1989, Bond and Midgley 1995, Schwilk 2003, Fernandes and Cruz 2012, McAllister et al. 2012, Pausas et al. 2012, Schwilk 2015). Some studies, for example, have conceptually equated flammability parameters measured in the lab (ignitability, combustibility and sustainability) to fire rate of spread, fire intensity, and residence time occurring during wildfires (Gill and Zylstra 2005). Although lab flammability tests should not be used solely as a surrogate for directly determining flammability at landscape level (Schwilk and Caprio 2011), these tests are essential for understanding some flammability components that operate at higher scales. Furthermore, their results can be used as inputs to models that predict fire behavior at landscape levels. However, the relation between flammability as assessed in the laboratory and flammability at stand or landscape level is often limited by factors associated with the scale of experimentation. Exposure of individual plant parts to heat under lab 


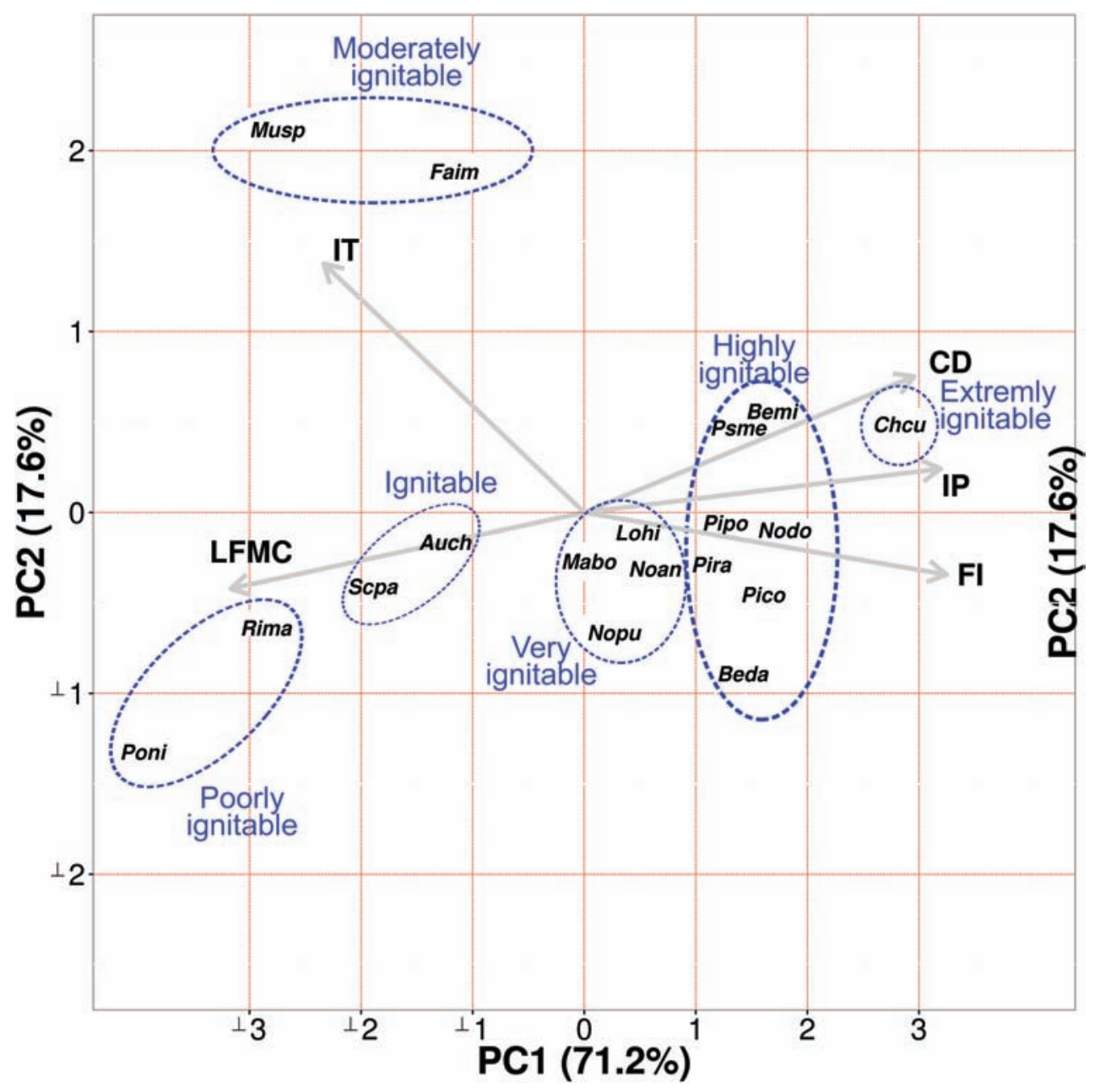

Figure 3. PCA and hierarchical cluster results. Vectors represent correlations between leaf ignition parameters and principal components 1 and 2. Dotted circles group species according the ignition clusters. LFMC, live fuel moisture content; IP, ignition percentage; $\mathrm{FI}$, flame index; CD, combustion duration; and IT, ignition time. Pipo, Pinus ponderosa; Psme, Pseudotsuga menziesii; Pico, Pinus contorta; Pira, Pinus radiata; Poni, Populus nigra; Noan, Nothofagus antarctica; Auch, Austrocedrus chilensis; Lohi, Lomatia hirsuta; Scpa, Schinus patagonicus; Nopu, Nothofagus pumilio; Mabo, Maitenus boaria; Nodo, Nothofagus dombeyi; Chcu, Chusquea culeou; Faim, Fabiana imbricata; Musp, Mulinum spinosum; Beda, Berberis darwinii; Bemi, B. microphylla; Rima, Ribes magellanicum;

conditions does not always recreate what may occur during wildfires to plants as a whole, or to a group of plants growing together in stands or at landscape level (Fernandes and Cruz 2012, Schwilk 2015). Sometimes the heat-transfer processes that operate in the real world cannot be realistically reproduced in the laboratory, and the corresponding flammability metrics and their interpretation cannot be extrapolated beyond the experimental setting (Fernandes and Cruz 2012). On the other hand, outdoor experimental fires, which may be extremely useful for determining fire rate of spread, fire intensity, and residence time, are generally limited by operational, safety, and cost constraints (Fernandes and Cruz 2012). In this study, we determined, under lab conditions, the LFMC and leaf ignition characteristics of dominant native Patagonian plant species and compared them with those of four exotic conifers and a broadleaf tree species planted in the region.

\section{Relation between LFMC, Leaf Ignition, and Ignition Rating}

The relation between LFMC and ease of ignition reported in previous studies (Xanthopoulos and Wakimoto 1993, Jolly et al. 2012, Page et al. 2012, 2014, Bianchi and Defossé 2014, 2015, among others) was supported by our results. Although the ignition behavior of live fuels is influenced by many different factors besides moisture content (e.g., chemical components or foliage structure; Jervis et al. 2010, McAllister et al. 2012), the mean LFMC of the species analyzed in this study was closely related to their leaf ignition (Figure 2). In addition, ignition frequency, flame index, and combustion duration were highly positively correlated, and ignition time highly negatively correlated, with LFMC on almost all species studied (Figure 3). Although the mean LFMC of a particular species was negative related to its mean leaf ignition characteristics, the relation between LFMC and all the leaf ignition parameters was not always significant (Table S1). This intraspecies variability could be related to variations in chemical components or foliage structure, for example.

The four exotic conifers analyzed had lower values of LFMC than most native trees and had some of the highest ignition values (Figure 4 and Table 1). Only the native bamboo-like Chusquea culeou was more likely to ignite. This may explain, in part, why all the exotic conifers burn rapidly if the stands are dense and unmanaged (not properly thinned or pruned). Among native trees, Nothofagus dombeyi had similar leaf ignition characteristics to the exotic conifers. This species naturally grows in humid areas 


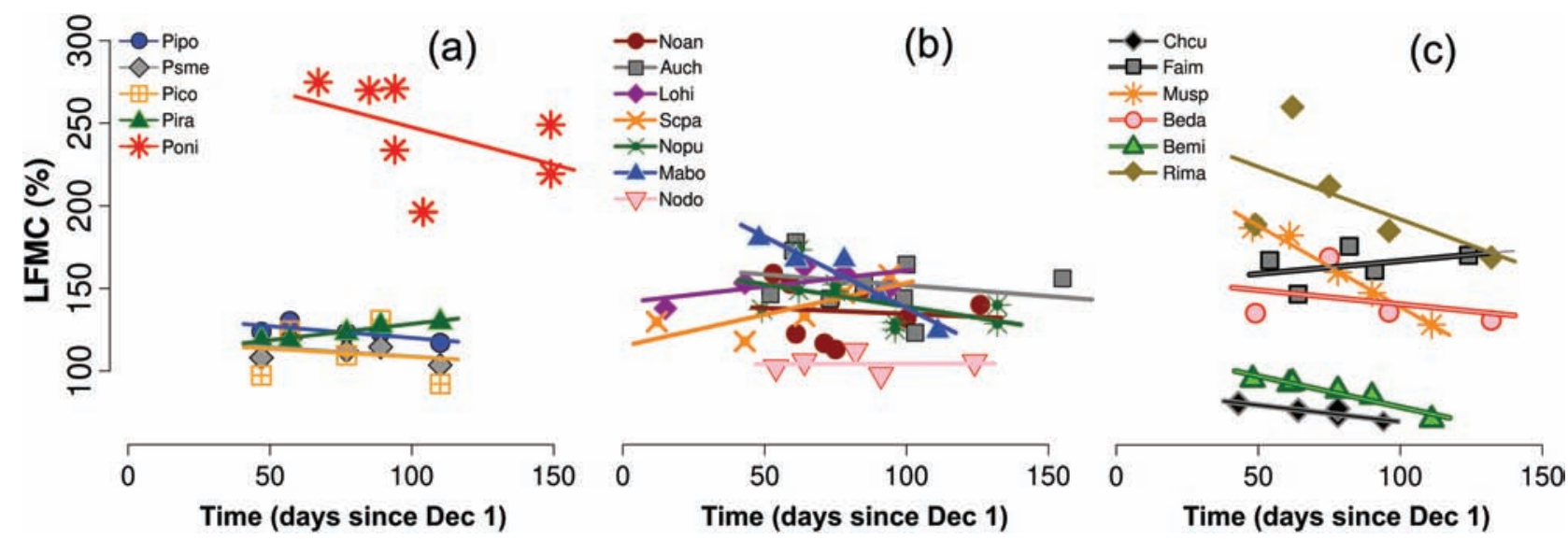

Figure 4. Foliar moisture content dynamics and the corresponding linear trends based on statistical modeling: (a) exotic trees, (b) native trees and (c) shrubs.

(western region of the precipitation gradient), so the highly ignitable characteristic of its leaves could be masked by the less fire-prone conditions of the surrounding natural environment. Nothofagus antarctica, $N$. pumilio, Maitenus boaria, and Lomatia birsuta, instead, were classified as very ignitable. Similar results for moisture content and flammability in native trees, including Nothofagus dombeyi had been observed by Ghermandi et al. (2016) in a wildland urban interface in northwestern Patagonia. In this region of Patagonia, N. pumilio forests are generally located at higher altitudes and above $N$. dombeyi forests. After periods of extreme drought, however, patches of both species may be reached by wildfires generally initiated in tall shrublands or in forests located at lower altitudes dominated by $N$. antarctica and Chusquea culeou (Mermoz et al. 2005). Communities dominated by Nothofagus antarctica occupy large areas in the Andean forest-steppe ecotone of northwestern Patagonia (CIEFAP and MAyDS 2016) and are spatially linked to human settlements and roads (Gowda 2013), generally known as wildland-urban interfaces. The closeness to human settlements, and the very ignitable condition of its leaves, makes the communities dominated by $N$. antarctica, accompanied by Lomatia birsuta and Maitenus boaria in the understory, the most fire-prone areas in the region (Mermoz et al. 2005).

It is important to note that LFMC of both Austrocedrus chilensis (widely distributed and a dominant tree species in the Andean piedmont) and Maitenus boaria decreased during the fire season (Figure 4 and Table S2). Moreover, these two species are among the few in which leaf ignition parameters are strongly related to within-species LFMC variations (Table S1). For that reason, although the cluster analysis classified Austrocedrus chilensis as ignitable and Maitenus boaria as very ignitable (Figure 4), when the season advances and their LFMC decreases, their leaf ignition increases, and then both species may behave as very ignitable and highly ignitable, respectively. Among shrubs, Berberis microphylla and B. darwinii were classified as highly ignitable, whereas the other shrub species were classified as moderately or poorly ignitable. The LFMC of Populus nigra was very high, and its leaf ignition parameters nearly coincide with those reported for the related trembling aspen (P. tremuloides Michx.) in North America (Van Wagner 1967). Trembling aspen also had a significantly higher LFMC and lower ignitability than five North American conifers. These results suggest that planting black poplar within conifer plantations in Patagonia, either as lines or as interspersed individuals, can create fire barriers and help reduce fire risk and flammability at stand levels (Bianchi and Defossé 2015).

\section{LFMC Dynamics}

In comparison with other regions of the world, the LFMC range that we found in the conifers species $(-87-141 \%)$ is below those $(-140-200 \%)$ reported for the same species grown in North America (Agee et al. 2002). Pinus contorta had a mean LFMC of $-111.0 \%$, similar to that found in north-central Colorado and western Montana, USA (Jolly et al. 2012). Values for $P$. ponderosa and $P$. contorta are also similar to those found by Jolly and Hadlow (2012). Moreover, in these studies, as in our results in northwestern Patagonia, the LFMC trend in conifers varied slightly during the summer season (Table S2 and Figure 4). It is important to notice that we identified the spring dip phenomenon (Van Wagner 1967, Chrosciewicz 1986, Jolly et al. 2016) in P. ponderosa and Pseudotsuga menziesii. Such low foliage moisture content during spring has been related to extreme fire behavior, and these minimum values of LFMC used for fire danger assessment (Agee et al. 2002). This spring dip in LFMC in the main conifers planted in the region, several months before the beginning of the fire season, could favor fire occurrence when the wildland fire control system is not fully operational. With regard to shrubs, as has been reported in other studies in the region (Oddi et al. 2016), in Mediterranean areas of southern Europe (Viegas et al. 2001, Castro et al. 2003, Pellizzaro et al. 2007) and in North America (Agee et al. 2002), the LFMC steadily decreased as the fire season advanced. This general trend may explain why the most extreme wildfires tend to occur in late summer in this region of Patagonia.

\section{Daily Variation of LFMC in Pinus ponderosa}

We found only a small diurnal variation of LFMC in Pinus ponderosa. As the season progressed, daily LFMC decreased more rapidly (Figure 5a-n). Similar to our results, the minimum LFMC around noon during the first part of the fire season was also reported by Agee et al. (2002) in August, and by Philpot (1965) in late June and in mid-July in the Northern Hemisphere. Philpot (1965) also found the minimum LFMC around 15:00-18:00 later in the fire season (late September). These variations along the season 

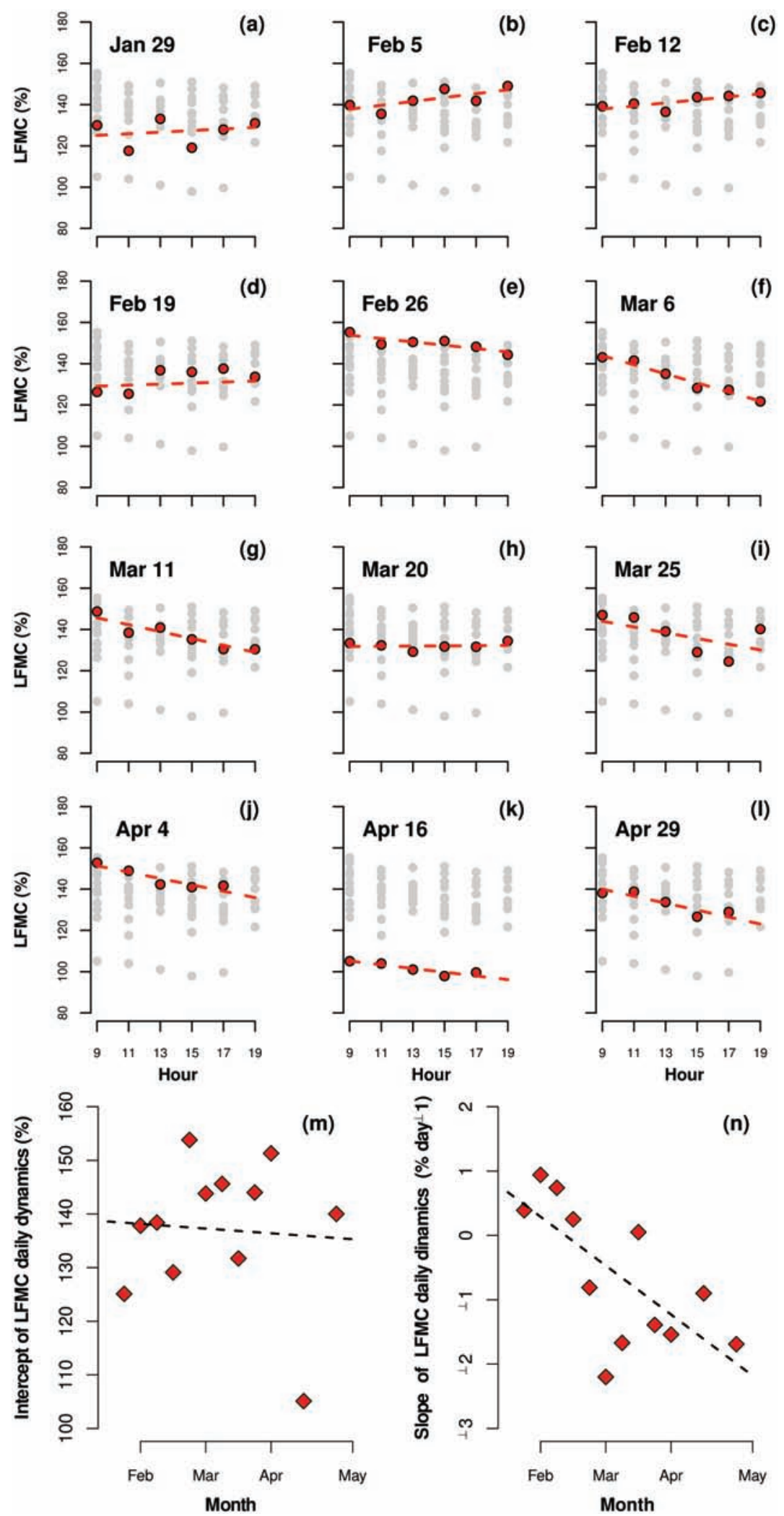

Figure 5. (a-I) daily variation of LFMC (response variable) in Pinus ponderosa (highlighted dots) plotted against the time of the day (fixed effect/predictor at data level) for every sampling date during the 2008 fire season. Gray circles represent all the LFMC values measured during the season, and dotted lines represent the adjusted model for each day (random effect). Below, trends of the intercepts (m) and the slopes (n) of these adjusted curves during the fire season (fixed effect/predictor at day level); dotted lines represent the fitted curve of the model for those intercepts and slopes.

and during a specific day could influence fire behavior and should be considered in fire danger assessments. Our model suggests that the initial LFMC at 09:00 remains almost constant for the entire fire season (Figure $5 \mathrm{~m}$ ). However, this result is highly influenced by LFMC hourly dynamics observed on 16 April 2008, when we measured the lowest LFMC values of the season. If this particular 
value is removed from the analyses, the LFMC at 09:00 would increase during the season. Further research is suggested to improve our understanding about daily LFMC dynamics.

In summary, leaves from the introduced conifers are more ignitable than most of the native species, with the exception of the bamboo-like Chusquea culeou, the shrub Berberis microphylla, and the tree Nothofagus dombeyi (Table 1). However, landscape-level flammability also depends on the plant structure, architecture, and other plant traits, and their arrangement in the landscape (Schwilk 2003, Kuljian and Varner 2013, Cruz et al. 2017). Examples taken from different conifers stands burned in Patagonia may help illustrate this issue. One example is presented by different stands composed of Pinus radiata, $P$. contorta, and Pseudotsuga menziesii, planted about 40-45 years ago at very high densities (2500 trees ha ${ }^{-1}$ ). Plantations grew, their canopies closed, and, because of competition and lack of light, native vegetation disappeared from their understory. Fires resulting from arsonburned these plantations in 1987 and 1999, and again in 2012 and 2015. These recurrent fires initiated a secondary succession path that not only self-perpetuated the non-native species, but also triggered invasive behavior in nearby areas (Raffaele et al. 2015). Another emblematic fire in this region occurred in 1990 (Dentoni et al. 1999). This extreme wildfire burned near 20,000 hectares of rangelands, of which about 1,000 hectares were of unmanaged stands of Pinus ponderosa and P. contorta. On the other hand, in a 25-year-old Pseudotsuga menziesii plantation caught by a wildfire, the tree mortality in unmanaged plots was $100 \%$ and steadily declined to 25,10 , and $5 \%$ as stand densities decreased to 900,700 , and 500 trees $\mathrm{ha}^{-1}$, respectively (Godoy et al 2013). All plots included the same species grown in the same place, i.e., the LFMC and leaf ignition characteristics were expected to be similar among trees. Therefore, it is reasonable to suppose that the differences in flammability and fire behavior among stands were because of different stand management. Similar results were observed when another wildfire caught a Pinus ponderosa plantation that, having received appropriate thinning and pruning treatments and residues removed, successfully survived with only minor bole damage (Davel et al. 2015).

\section{Concluding Remarks}

Fire is a ubiquitous phenomenon that has shaped the structure and functioning of vegetation of most ecosystems at global scale. However, the influence of plant traits on vegetation flammability is still under discussion. In this study, we provided data showing some flammability constituents for dominant native Patagonian plant species and made comparisons with those of exotic conifers and a broadleaf tree species planted in the region. We found that the introduced conifers were, in general, more ignitable than most of the native species analyzed. This basic information is essential for the subsequent development of fire behavior models and the correct determination of flammability at stand or landscape levels (Fernandes and Cruz 2012). Further studies are required to continue improving our understanding about other factors that may link lab with field studies. Among them are the development of more complex physical models describing what happens with LFMC during a fire, or the study of the relation of the chemical composition and structure of live foliage with flammability (Jervis et al. 2010, McAllister et al. 2012). Finally, to apply these results to stand or landscape levels, more detailed characterization of fuel complexes in specific vegetation types, followed by experimental fires, should be necessary.

\section{Supplementary Materials}

Supplementary data are available at Forest Science online.

\section{Funding}

The European Commission within the Sixth Framework Programme supported part of this research through the Integrated Project FIRE PARADOX (Project no. FP6-018505).

\section{Literature Cited}

Agee, J.K., 1993. Fire ecology of Pacific Northwest forests. Island Press, Washington, DC. 505 p.

Agee, J.K., C.S. Wright, N. Williamson, and M.H. Huff. 2002. Foliar moisture content of Pacific Northwest vegetation and its relation to wildland fire behavior. Forest Ecol. Manag. 167:57-66.

Bates, D., M. Maechler, B. Bolker, and S. Walker. 2015. Fitting linear mixed-effects models using lme4. J. Stat. Softw. 67(1):1-48. doi:10.18637/jss.v067.i01.

Bianchi, L.O., And G.E. Defossé. 2014. Ignition probability of fine dead surface fuels in native Patagonia forests of Argentina. Forest Syst. 23:129-138.

Bianchi, L.O., and G.E. Defossé. 2015. Live fuel moisture content and leaf ignition of forest species in Andean Patagonia, Argentina. Int. J. Wildland Fire 24:340-348. doi:10.1071/WF13099.

Blackhall, M., E. Raffaele, and T.T. Veblen. 2012. Is foliar flammability of woody species related to time since fire and herbivory in northwest Patagonia, Argentina? J. Veg. Sci. 23:931-941. doi:10.1111/j.1654-1103.2012.01405.x.

Bond, W.J., AND J.J. Midgley. 1995. Kill thy neighbour: An individualistic argument for the evolution of flammability. Oikos 73(1):79.

Brooks, M.L., C.M. D’Antonio, D.M. Richardson, J.B. Grace, J.E. Keeley, J.M. DiTomaso, R.J. Hobbs, M. Pellant, and D. Pyke. 2004. Effects of invasive alien plantas on fire regimes. BioScience 54:677-688.

Buduba, C.G. 2006. Modificaciones en el pH y contenido de materia orgánica en suelos del ecotono estepalbosque andino-patagónico por implantación de pino ponderosa. PhD thesis. Facultad de Agronomía, Universidad de Buenos Aires. 201 p.

Castro, F., A. Tudela, and M. Sebastià. 2003. Modeling moisture content in shrubs to predict fire risk in Catalonia (Spain). Agric. For. Meteorol. 116:49-59. doi:10.1016/S0168-1923(02)00248-4.

Chrosciewicz, Z. 1986. Foliar moisture content variations in four coniferous tree species of central Alberta. Can. J. For. Res. 16:157-162.

Ciefap, and Mayds. 2016. Actualización de la Clasificación de Tipos Forestales y Cobertura del Suelo de la Región Bosque Andino Patagónico. Informe Final. Available online at https://drive.google. com/open?id=0BxfNQUtfxxeaUHNCQm9lYmk5RnM. 101 p.

Cruz, M.G., M.E. Alexander, and M.P. Plucinski. 2017. The effect of silvicultural treatments on fire behaviour potential in radiata pine plantations of South Australia. Forest Ecol. Manag. 397:27-38.

Davel, M.M., G. Caballé, H. Gonda, L. Chauchard, R. Sbrancia, AND L. Bulgarelli. 2015. Los tratamientos silvícolas. P. 191-243 in: Manual de Buenas Prácticas para el manejo de plantaciones forestales en el noroeste de la Patagonia. Chauchard, L., M.C. Frugoni, and C. NowAK (eds.). UCAR—Ministerio de Agroindustria, Buenos Aires.

Defossé, G.E. 1995. Germination, emergence, and survival of Festuca spp. seedlings in a steppe of Patagonia, Argentina. PhD thesis. College of Graduate Studies, University of Idaho. UMI Dissertation Services. Bell \& Howell Company, Ann Arbor, MI. 113 p. 
Defossé, G.E. 2015. ¿Conviene seguir fomentando las plantaciones forestales en el norte de la Patagonia? Ecol. Austral. 25:93-100.

Defossé, G.E., G. Loguercio, F.J. Oddi, J.C. Molina, and P.D. Kraus. 2011. Potential CO2 emissions mitigation through forest prescribed burning: A case study in Patagonia, Argentina. Forest Ecol. Manag. 261:2243-2254. doi:10.1016/j.foreco.2010.11.021.

Defossé, G.E., M.M. Godoy, L.O. Bianchi, N.S. Lederer, AND C. Kunst. 2015. Fire history, fire ecology and management in Argentine Patagonia: From ancient times to nowadays, P. 177-209 in Current international perspectives on wildland fires, mankind and the environment, Leblon, B., and M.E. Alexander (eds.). Nova Science Publishers, New York.

Dentoni, M.C., G.E. Defossé, N.F. Rodríguez, M.M. Muñoz, And H. Соцомв. 1999. Estudio de Grandes Incendios: El caso de la Ea. San Ramón en Bariloche, Río Negro-Patagonia Argentina. Plan Nacional de Manejo del Fuego-CIEFAP_GTZ. Esquel, Chubut. 94 p.

Dimitrakopoulos, A.P., and A.M. Bemmerzouk. 2003. Predicting live herbaceous moisture content from a seasonal drought index. Int. J. Biometeorol. 47:73-79.

Fernandes, P.M., And M.G. Cruz. 2012. Plant flammability experiments offer limited insight into vegetation-fire dynamics interactions. New Phytol. 194(3):606-609.

Fraser, I.P., R.J. Williams, B.P. Murphy, J.S. Camac, and P.A. Vesk. 2016. Fuels and landscape flammability in an Australian alpine environment. Aust. J. Ecol. 41:657-670. doi:10.1111/aec.12355.

Gelman, A., AND J. Hill, 2007. Data analysis using regression and multilevel/hierarchical models. Cambridge University Press, Cambridge, UK. $648 \mathrm{p}$.

Ghermandi, L., N.A. Beletzky, M.I. de Torres Curth, and F.J. Oddi. 2016. From leaves to landscape: A multiscale approach to assess fire hazard in wildland-urban interface areas. J. Environ. Manage. 183:925937. doi:10.1016/j.jenvman.2016.09.051.

Gill, A.M., And P. Zylstra. 2005. Flammability of Australian forests. Aust. For. 68:87-93.

Godoy, M.M., G.E. Defossé, L.O. Bianchi, M.M. Davel, and T.E. Withington. 2013. Fire-caused tree mortality in thinned Douglas-fir stands in Patagonia, Argentina. Int. J. Wildland Fire 22:810-810. doi:10.1071/WF12107.

Gonda, H.E., M.M. Davel, N. Bonino, L. Contardi, S. Foccarazzo, F. Calvi, V. Rusch, and U. Mele. 2015. El establecimiento de las plantas. P. 165-190 in Manual de Buenas Prácticas para el manejo de plantaciones forestales en el noroeste de la Patagonia. Chauchard, L., M.C. Frugoni, and C. Nowak (eds.). UCAR-Ministerio de Agroindustria, Buenos Aires.

GonZÁLeZ, S. 2011. Estrategias de regeneración post-fuego en pastizales del Noroeste Patagónico: Un enfoque experimental. $\mathrm{PhD}$ thesis. Universidad Nacional del Comahue, Bariloche, Argentina. 175 p.

GowDA, J.A. 2013. ¿Qué protegemos y qué deberíamos proteger con la ley de bosques? Aportes para la primera revisión del ordenamiento territorial de los bosques de Río Negro. Revista de la Asociación Argentina de Ecologia de Paisajes 4(2):46-62.

Jervis, F.X., G. Rein, A. Simeoni, and J.L. Torero. 2010. The role of moisture in the burning of live and dead pine needles in Proceedings of the 6th International Seminar on Fire and Explosion Hazards, Leeds, April.

Jobbagy, E.G., O.E. Sala, and J.M. Paruelo. 2002. Patterns and controls of primary production in the Patagonian steppe: A remote sensing approach. Ecology 83:307-319. doi:10.2307/2680015.

Jolly, W.M., AND A.M. HadLow. 2012. A comparison of two methods for estimating conifer live foliar moisture content. Int. J. Wildland Fire 21:180-185.

Jolly, W.M., R.A. Parsons, A.M. Hadlow, G.M. Cohn, S.S. McAllister, J.B. Popp, R.M. Hubbard, And J.F. Negron. 2012. Relationships between moisture, chemistry, and ignition of Pinus contorta needles during the early stages of mountain pine beetle attack. Forest Ecol. Manag. 269:52-59. doi:10.1016/j.foreco.2011.12.022.

Jolly, W.M., J. Hintz, R.L. Linn, R.C. Kropp, E.T. Conrad, R.A. Parsons, and J. Winterkamp. 2016. Seasonal variations in red pine (Pinus resinosa) and jack pine (Pinus banksiana) foliar physiochemistry and their potential influence on stand-scale wildland fire behavior. Forest Ecol. Manag. 373:167-178. doi:10.1016/j. foreco.2016.04.005.

Keeley, J.E., W.J. Bond, R.A. Bradstock, J.G. Pausas, and P.W. Rundel. 2012. Fire in Mediterranean ecosystems: Ecology, evolution and management. Cambridge University Press, Cambridge, UK. 525 p.

Kitzberger, T., and T.T. Veblen. 2003. Influences of climate on fire in Northern Patagonia, Argentina. P. 296-321 in Fire and climatic change in temperate ecosystems of the western Americas, Veblen T.T., W.L. Baker, G. Montenegro, and T.W. Swetnam (eds.). Springer-Verlag, New York. Available online at http://link.springer. com/10.1007/0-387-21710-X_10.

Kuljian, H., AND J.M. VARner. 2013. Foliar consumption across a sudden oak death chronosequence in laboratory fires. Fire Ecol. 9(3):33-44.

La Manna, L. 2005. Caracterización de los suelos bajo bosque de Austrocedrus chilensis a través de un gradiente climático y topográfico en Chubut, Argentina Bosque (Valdivia) 26:137-153.

McAllister, S., I. Grenfell, A. Hadlow, W.M. Jolly, M. Finney, and J. Cohen. 2012. Piloted ignition of live forest fuels. Fire Saf. J. 51:133142. doi:10.1016/j.firesaf.2012.04.001

Mermoz, M., T. Kitzberger, and T.T. Veblen. 2005. Landscape influences on occurrence and spread of wildfires in Patagonian forests and shrublands. Ecology 86(10):2705-2715.

Mutch, R.W. 1970. Wildland fires and ecosystems-A hypothesis. Ecology 51(6):1046-1051.

Oddi, F.J., And L. Ghermandi. 2016. Fire regime from 1973 to 2011 in north-western Patagonian grasslands. Int. J. Wildland Fire 25(9):922932. doi:10.1071/WF15211.

Oddi F.J., L. Ghermandi, and L.O. Bianchi. 2016. Dinámica de la humedad de la vegetación en pastizales del noroeste de la Patagonia Argentina. P. 416-420 in Proceedings of the V Jornadas Forestales Patagónicas - III Jornadas Forestales de Patagonia Sur-Ecofuego II, Esquel, Argentina, November.

Orellana, I., and E. Raffaele. 2010. The spread of the exotic conifer Pseudotsuga menziesii in Austrocedrus chilensis forests and shrublands in northwestern Patagonia, Argentina. N. Z. J. For. Sci. 40(2010):199-209

Page, W.G., M.J. Jenkins, And J.B. Runyon. 2012. Mountain pine beetle attack alters the chemistry and flammability of lodgepole pine foliage. Can. J. For. Res. 42(8):1631-1647.

Page, W.G., M.J. Jenkins, and J.B. Runyon. 2014. Spruce beetleinduced changes to engelmann spruce foliage flammability. For. Sci. 60(4):691-702.

Pausas, J.G., G.A. Alessio, B. Moreira, and G. Corcobado. 2012. Fires enhance flammability in Ulex parviflorus. New Phytol. 193(1):18-23.

Pellizzaro, G., P. Duce, A. Ventura, and P. Zara. 2007. Seasonal variations of live moisture content and ignitability in shrubs of the Mediterranean Basin. Int. J. Wildland Fire 16:633-641. doi:10.1071/ WF05088.

Peña-Fernández, E., and L. Valenzuela-Palma. 2008. Incremento de los incendios forestales en bosques naturales y plantaciones forestales en Chile. P. 595-612 in Proceedings of the Second International Symposium on Fire Economics, Planning, and Policy: A Global View. General Technical Report PSW-GTR-208, González-Cabán, A. (ed.). USDA Forest Service, Pacific Southwest Research Station, Albany, CA.

Philpot, C.W. 1965. Diurnal Fluctuation in Moisture Content of Ponderosa Pine and Whiteleaf Manzanita Leaves (No. Research Note PSW-RN-067). USDA Forest Service, Pacific Southwest Forest and Range Experiment Station, Berkeley, CA. 7 p. 
Pinheiro, J.C., And D.M. Bates. 2006. Mixed-effects models in $S$ and S-PLUS. Springer-Verlag New York. 528 p.

Pinheiro, J.C., D.M. Bates, S. DebRoy, and R Core Team. 2016. nlme: Linear and nonlinear mixed effects models. R package version 3.1-131.

R Core Team. 2015. R: A language and environment for statistical computing. $\mathrm{R}$ Foundation for Statistical Computing, Vienna. Available online at https://www.R-project.org/.

Raffaele, E., M.A. Nuñez, and M.A. Relva. 2015. Plantaciones de coníferas exóticas en Patagonia: Los riesgos de plantar sin un manejo adecuado. Ecol. Austral. 25:89-92.

Rothermel, R.C., AND H.E. ANDERSON. 1966. Fire spread characteristics determined in the laboratory. USDA Forest Service, Intermountain Forest and Range Experiment Station, Research Paper INT-30, Ogden, UT. 34 p.

Sarasola, M.M., V.E. Rusch,T.M. Schlichter, and C.M. Ghersa. 2006. Invasión de coníferas forestales en áreas de estepa y bosques de ciprés de la cordillera en la Región Andino Patagónica. Ecol. Austral. 16(2):143-156.

ScHwilk, D.W. 2003. Flammability is a niche construction trait: Canopy architecture affects fire intensity. Am Nat. 162:725-733. doi: $10.1086 / 379351$.

Schwıl, D.W. 2015. Dimensions of plant flammability. New Phytol. 206(2):486-488.

Schwilk, D.W., AND A.C. Caprio. 2011. Scaling from leaf traits to fire behaviour: Community composition predicts fire severity in a temperate forest: Leaf length and fire behaviour. J. Ecol. 99(4):970-980.

Simberloff, D., M.A. Nuñez, N.J. Ledgard, A. Pauchard, D.M. Richardson, M. Sarasola, B.W. Van Wilgen, S.M. Zalba, R.D. Zenni, R. Bustamante, E. Peña, and S.R. Ziller. 2009.
Spread and impact of introduced conifers in South America: Lessons from other southern Hemisphere regions. Aust. J. Ecol. 35:489-504. doi:10.1111/j.1442-9993.2009.02058.x.

Troumbis, A.S., and L. Trabaud. 1989. Some questions about flammability in fire ecology. Acta Oecol., Oecol. Plant., 10:167-175.

VAN WAGNer, C.E. 1967. Seasonal variation in moisture content of eastern canadian tree foliage and the possible effect on crown fires. Minister of Forestry and Rural Development, Forestry Branch. Departmental Publication 1204, Ottawa. 15 p.

Veblen, T.T., T. Kitzberger, and A. Lara. 1992. Disturbance and forest dynamics along a transect from Andean rain forest to Patagonian shrubland. J. Veg. Sci. 3:507-520. doi:10.2307/3235807.

Veblen, T.T., T. Kitzberger, E. Raffaele, M. Mermoz, M.E. González, J.S. Sibold, ANd A. Holz. 2008. The historical range of variability of fires in the Andean-Patagonian Nothofagus forest region. Int. J. Wildland Fire 17:724-741. doi:10.1071/WF07152.

Viegas, D.X., J. Piñol, M.T. Viegas, and R. Ogaya. 2001. Estimating live fine fuels moisture content using meteorologically-based indices. Int. J. Wildland Fire 10:223-240.

Villalba, R. 1995. Climatic influences on forest dynamics along the foreststeppe ecotone in northern Patagonia. PhD thesis, University of Colorado, Boulder, CO.

Walter, H., ANd H. Lieth. 1960-1967. Klimadiagramm-Weltatlas. Fischer-Verlag, Jena.

Wright, H.A., and A.W. Bailey. 1982. Fire ecology. Wiley, New York. 528 p.

Xanthopoulos, G., and R.H. WaKimoto. 1993. Time to ignition-temperature-moisture relationship for branches of three western conifers. Can. J. For. Res. 23:253-258. 